\title{
A presença religiosa brasileira no Exterior: o caso da Igreja Universal do Reino de Deus
}

\author{
ARI PEDRO ORO
}

$\mathrm{E}$

STE TEXTO VERSA sobre o pentecostalismo brasileiro transnacional, tomando como foco de observação e análise da Igreja Universal do Reino de Deus (IURD). Por pentecostalismo brasileiro transnacional entendo as igrejas do segmento pentecostal que a) surgiram no Brasil e foram fundadas por brasileiros; b) incorporaram em seus ritos e doutrina elementos da religiosidade popular, notadamente a crença em forças invisíveis que interferem no cotidiano, entre elas a crença no poder de satanás; c) empreenderam uma inserção internacional afirmando a sua condição brasileira ao mesmo tempo em que são reconhecidas como tais.

Inscrevem-se nessa perspectiva algumas igrejas da segunda e terceira ondas pentecostais, segundo a tipologia proposta por Paul Freston ${ }^{1}$, sobretudo as igrejas Deus é Amor, que está implantada em 136 países $^{2}$; a igreja Renascer em Cristo, em onze países; a Igreja Internacional da Graça de Deus, em sete países³; e, sobretudo, a Igreja Universal do Reino de Deus, presente hoje em oitenta países.

Evidentemente que há outras igrejas evangélicas brasileiras no exterior, bem como outras religiões. É o caso das religiões da Ayauasca (Santo Daime, União do Vegetal e Barquinha) e das religiões afro-brasileiras, como o Candomblé, o Batuque, o Xangô, a Quimbanda e a Umbanda, que foram implantadas nos países do Mercosul, da América do Norte e da Europa, por agentes religiosos brasileiros dessas religiões.

Mas são, como disse, sobretudo algumas igrejas brasileiras do campo pentecostal que foram mais longe no processo de deslocamento para o exterior. Vale esclarecer que não estamos falando de missionários brasileiros no exterior, das igrejas católica ou evangélicas históricas, e mesmo pentecostal tradicional, como a Assembléia de Deus, que deixam o país para cumprir o ministério em organizações e instituições religiosas homólogas já existentes em países que os acolhem. Nos casos acima mencionados, trata-se de agentes religiosos brasileiros, representantes de igrejas e religiões brasileiras, que se instalam no exterior para abrir um novo mercado religioso, ingressando, assim, num campo de competição com as outras igrejas e religiões locais para lograr atrair fiéis à sua oferta religiosa. 
É justamente isto que veremos no caso da Igreja Universal do Reino de Deus. Interessa-nos, sobretudo, explorar, seguindo as sugestões de R. Segato para os estudos sobre transnacionalização religiosa (Segato, 1997), como essa igreja se localiza e como ela se autoctoniza. Nesse sentido, veremos três exemplos em que ela demonstra sensibilidade para encontrar espaços e se adaptar aos contextos culturais locais, podendo-se afirmar que neles ela obteve êxito. Tratase da Argentina, de Portugal e da África do Sul. E, contrariamente a isto, veremos três outros exemplos em que ela encontrou problemas para se desenvolver e sua presença é débil. É o caso do Uruguai, do México e da França.

\section{A transnacionalização da Igreja Universal do Reino de Deus}

O termo transnacionalização, e outros correlatos surgidos nos últimos anos como globalização, mundialização e desterritorialização, são controvertidos e polissêmicos ${ }^{4}$. Neste texto sigo a definição de transncionalização dada por Badie e Smouts, ou seja: "toute relation qui, par volonté délibérée ou par destination, se construit dans l'espace mondial au-delà du cadre étatique national et qui se réalise en échappant au moins partiellement au controle ou à l'action médiatrice des États" (Badie et Smouts, 1995, p. 70).

Segundo os mesmos autores, há uma diversidade de relações transnacionais e, voluntariamente ou não, todas questionam a soberania dos Estados e sua pretensão de reivindicar o direito exclusivo de agir na cena internacional. Distinguem os fluxos produzidos por organizações não governamentais e os que resultam da composição de ações individuais múltiplas. Os fluxos religiosos organizados pelas igrejas, associações culturais, seitas ou grupo de pregadores, vinculamse à primeira categoria. À segunda, de acordo com os autores, correspondem os fluxos demográficos que ocorrem por agregação de motivações individuais (Badie et Smouts, 1995, p. 71) $)^{5}$.

A expansão internacional da Igreja Universal resulta de uma decisão da própria Igreja segundo seus cálculos e interesses, e ela se relaciona com as instâncias estatais somente naquilo que for exigido legalmente: passaporte, visto, registro, impostos. O procedimento usual é sempre o mesmo. A cúpula dirigente efetua um levantamento de países e cidades em que pensa instalar a Igreja. Nesta escolha é levada em consideração a possível clientela, e, sobretudo, a presença de brasileiros ou hispânicos. Decidido o país e a cidade, são enviados para lá um ou mais pastores que alugam um espaço, de preferência cinemas ou outros de tamanho razoável desativados, situados em lugar de grande circulação de pessoas, para dar início ao trabalho religioso.

O início da expansão internacional da IURD data de 1985, quando abre uma igreja no Paraguai. Em 1986, instala-se nos Estados Unidos e, em 1989, na Argentina, no Uruguai e em Portugal (Freston, 2001). No princípio a expansão é lenta. O ritmo começa a se acelerar a partir dos anos de 1990. Em 1995, o número de templos instalados no exterior é estimado em 221; em 1998 já era de 
quinhentos e de mil templos em 2001. E o crescimento continua. Segundo A. Corten, a IURD é encontrada hoje em todos os países da América Latina, menos no Haiti. Também é encontrada na metade dos países da África, no Canadá e nos Estados Unidos, e na Europa numa dúzia de países. Ela se espalha também nos países do leste europeu e em alguns países da Ásia, como Japão, Filipinas, Índia. (Corten, 2002). No total são oitenta países. No entanto, na maioria deles a sua implantação é simbólica. Poucos são os países em que a Universal possui mais de cinqüenta templos. Podemos enumerar, na América latina, além do Brasil, é claro, Argentina e Venezuela; na Europa, Portugal e Reino Unido; na África, Costa do Marfil, Moçambique e África do Sul; e, finalmente, os Estados Unidos.

Vamos nos ater agora a três países onde a Universal não somente conhece uma expansão significativa no plano quantitativo, mas também conseguiu encontrar brechas para se enraizar nas culturas locais ${ }^{6}$.

\section{Uma igreja que prospera}

\section{A Igreja Universal na Argentina}

É no final da década de 1980 que a Universal abre seus primeiros templos na Argentina, primeiramente em Buenos Aires. No princípio ocorre um crescimento lento. Mas, a partir de 1995, conhece um crescimento constante, tendo hoje cerca de oitenta templos situados nas principais cidades do país.

Ali a Universal consegue acolhida preferencialmente junto aos segmentos superiores das camadas baixas da sociedade e junto aos segmentos inferiores das camadas médias urbanas. Trata-se de parcelas sociais que, tal como no Brasil, estão sofrendo fortemente os efeitos recessivos da política neoliberal e que esperam encontrar através da mediação da Igreja a possibilidade de superação da crise socioeconômica e de realização do sonho de bem-estar não encontrado na esfera social (Oro e Seman, 2001).

Embora seja difícil estipular o número de fiéis argentinos, Seman vê na capacidade de mobilização social a possibilidade de se ter uma idéia aproximada. Refere que no natal de 2001 a IURD reuniu, num estádio de futebol de Buenos Aires, entre quarenta e cinqüenta mil pessoas (Seman, 2003).

Como no Brasil, também na Argentina a Universal se faz presente na mídia, ocupando horários noturnos no rádio e na televisão, além de difundir e distribuir o jornal Folha Universal. Também executa seguidas campanhas de assistência social, visando assim a conquistar melhor legitimidade, sobretudo nas províncias e cidades do interior onde tem sido mais hostilizada em razão do seu estilo proselitista agressivo.

Mas, o êxito da Universal na Argentina está diretamente relacionado a uma importante adaptação de sua doutrina aos aspectos da cultural local.

Com efeito, um dos importantes componentes da doutrina da Universal é a concepção do demônio como causador dos males e das aflições em geral. No 
Brasil, a satanização ganha a cara das religiões afro-brasileiras. Na Argentina, a figura do demônio também faz parte das sensibilidades religiosas, sobretudo do catolicismo popular, embora permaneça relativamente na penumbra. Entretanto, considerando que na sociedade Argentina as religiões afro-brasileiras não possuem a mesma inserção e presença social do que no Brasil, a demonização recai sobre os curandeiros, o mau-olhado, a inveja, e, sobretudo - e mostrando sua capacidade adaptativa aos padrões argentinos - os pastores introduzem outra apelação. Eles "combinam os exorcismos com a adaptação a noções mais próximas aos aspectos psicologizados da cultura dos fiéis argentinos" (Seman e Moreira, 1998, p. 103). Em outras palavras, neste país os demônios são identificados menos com as entidades do panteão afro-brasileiro, como ocorre no Brasil, e mais com o mal-estar percebido como tendência psicológica, estado de ânimo etc. Assim, a Universal não renuncia à demonização, mas a reformula, unindo os elementos próprios da sociedade Argentina com o seu discurso povoado de entes malignos que molestam os fiéis (Seman e Moreira, 1998, p. 104).

Neste caso, como se pode notar, "os fiéis assumem o demônio como causa de mal-estar que antes se explicavam de outra maneira e a igreja modifica o repertório das situações demonizáveis assim como o estilo em que isto se realiza” (Seman e Moreira, 1998, p. 104).

Portanto, para ganhar terreno na Argentina a Universal oferece algo que uma parte dos fiéis das classes médias-baixas e baixas argentinas não encontram nas diversas variantes do pentecostalismo local. Ela interage com a cultura psicologizada e com a religiosidade popular Argentina, atribuindo ao demônio os males da vida urbana e moderna, tais como angústias existenciais, estresses e depressão, e colocando-se na condição de libertadora desses males mediante o exorcismo do satanás.

Assim sendo, para os fiéis argentinos da Universal, esta igreja não constitui um simples acréscimo ao número de igrejas pentecostais já existentes no país. Trata-se, antes, de um modo específico de ser pentecostal neste país, nos dias atuais.

\section{A Igreja Universal em Portugal}

A implantação da Universal em Portugal ocorreu no final de 1989, nos arredores de Lisboa, e constituiu-se numa etapa importante na estratégia expansionista da IURD para outros países europeus e africanos, sobretudo os de fala portuguesa (Freston, 2001). Isto porque, diz Marion Aubrée, existe “[...] des migrants d'origine portugaise dans presque toutes les capitales d'Europe de l'ouest et c'est à travers cette filière migratoire que l'IURD a commencé à se développer dans cette région du monde" (Aubrée, 2000, p. 155).

A implantação em Portugal ocorreu com algumas vantagens em relação à inserção em outros países: não houve a barreira do idioma para os pastores brasileiros; também não havia a barreira religiosa cultural uma vez que, tal como no 
Brasil, a maioria da população portuguesa é católica; e, enfim, ambos os países consolidaram a sua entrada numa economia neoliberal a partir da década de 1970 (Mafra, 2002).

Porém, ao se instalar em Portugal, a Universal se viu envolta em debates locais concernentes à invasão das seitas e seus malefícios. Mais tarde, e refletindo polêmicas que ocorriam no Brasil, a imprensa portuguesa reproduziu notícias sobre escândalos financeiros e interesses empresariais desta Igreja. No ano de 1996, os jornais noticiaram que a Universal estava sendo investigada pela justiça. Em 1999, ela voltou a ser notícia no bojo dos debates sobre a reformulação da Lei de Liberdade Religiosa, sancionada naquele ano.

Mas foi no ano de 1995 que a Universal foi mais fortemente alvo da ação xenofóbica. Isto deveu-se ao fato de vir a público, quase que simultaneamente mas antes do desejado pelos pastores, o interesse desta igreja em comprar o Coliseu do Porto e em encaminhar um partido político, o Partido da Gente.

O Coliseu do Porto é tido como a mais tradicional casa de espetáculos da cidade e, em agosto de 1995, a UAP (uma das principais seguradoras da região), sua proprietária, veio a público para informar que a Universal estava adquirindo aquele imóvel. Imediatamente, o sindicato dos artistas, intelectuais, políticos e parte da população expressaram publicamente seu repúdio. Três meses mais tarde um ato público de protesto em frente ao Coliseu foi transmitido pela televisão. Ouviu-se então ruídos xenófobos, embora a tônica geral dos discursos recaíssem sobre a defesa do prédio "símbolo da vida pública portuense". Uma semana mais tarde, o próprio presidente Mário Soares interveio no conflito. Finalmente, em janeiro de 1996 a então recém-formada "Sociedade dos Amigos do Coliseu do Porto" comprou o estabelecimento.

Igualmente, a tentativa de aderir a um partido político em Portugal não foi levada adiante, em razão das reações contrárias advindas de diversos segmentos da sociedade portuguesa. Conseqüentemente, o projeto político da Universal naufragou, da mesma forma como a tentativa de aquisição do Coliseu do Porto (Mafra, 2003).

Seja como for, essa foi a única tentativa da Universal de ingressar na vida política fora do Brasil. Isto não significa, porém, que esta igreja não tenha implicação e inserção social nos países em que se instala. Ela ocorre, por exemplo, pela sua presença na mídia e seu trabalho de assistência social.

No entanto, e para voltar a Portugal, se, por um lado, a Universal fracassou na tentativa de execução dos dois projetos mencionados, por outro lado, ela colheu frutos para o seu prosseguimento no país, sobretudo graças ao bispo Marcelo Brayner, então responsável pela Universal em Portugal, na medida em que ele soube

[...] reforçar exatamente aqueles aspectos mais libertários da influência iurdiana, ao disputar com firmeza o direito das pessoas a opiniões religiosas diversas, $\mathrm{o}$ 
direito ao comportamento como cidadão livre e igual perante a lei, e ao demonstrar menosprezo pelas atitudes persecutórias. Com isto, mobilizou favoravelmente a opinião pública portuguesa e indicou um caminho possível para a solidificação da instituição em Portugal, pautando o combate público, rigorosamente, pela força da lei (Mafra, 2002, p. 204).

Ademais, sublinha Mafra, por um lado, no Brasil e também em Portugal, a IURD sempre soube acionar a seu favor as "teorias persecutórias"; e, por outro lado, ela tem prestado a sua contribuição para a constituição do pluralismo religioso em Portugal (Mafra, 2002, pp. 63-65).

Portanto, malgrado a mobilização da mídia portuguesa e as atitudes sociais contrárias à Universal, ela não perdeu popularidade em Portugal,

tanto que em 1994 ela tinha treze salas em todo o país, e em 1999 já chegava a mais de noventa lugares. Isto significa que, tanto como no Brasil, os embates espetaculares entre imprensa e igreja pareciam provocar o resultado inverso do previsto: de $1995 \mathrm{em}$ diante [...] a igreja cresceu exponencialmente (Mafra, 2001, p. 9).

Além disso, tal como fizera no Brasil, desde a sua instalação em Portugal a Universal se preocupou em estruturar uma rede midiática, adquirindo emissoras de rádio quase falidas, transmitindo programas televisivos e editando o Jornal Tribuna Universal. Desta forma, ela se faz presente na vida pública portuguesa e dá visibilidade às suas atividades ritualísticas e às suas campanhas de assistência social $^{7}$.

Como para outros países, também para Portugal é difícil estimar o número de fiéis da IURD. Mafra menciona que, desde 1994, bispos e pastores da Universal anunciam possuir neste país um rebanho de mais de duzentos mil fiéis, cujo perfil social seria semelhante ao do Brasil: preferencialmente mulheres, com baixa escolaridade, pertencentes às camadas populares, embora também atraia um público de classe média e mesmo média alta (Mafra, 2003).

Clara Mafra chama a atenção para dois aspectos importantes para a compreensão do crescimento da Universal em Portugal. Em primeiro lugar, desde o princípio os pastores brasileiros ativaram uma retórica encantada sobre o nacional. Em outras palavras, enfatizaram a necessidade do enfrentamento de satanás em Portugal,

[...] um país que, segundo eles, vivia na "cauda de uma comunidade européia, quando seu lugar era a cabeça"; que tinha governantes tímidos no tratamento dos males internos; que contava com políticos que pouco se importavam com a situação dos idosos, dos presos, das crianças, dos desempregados, dos desqualificados educacionalmente (Mafra, 2003, p. 170).

Paul Freston também refere que a entrada da IURD em Portugal ocorreu quando este país ingressou na Comunidade Econômica Européia, fazendo com que parcelas sociais que não conseguiam realizar as aspirações suscitadas pela 
nova condição do país se aproximassem desta igreja em razão da pregação da Teologia da Prosperidade (Freston, 2001).

Em segundo lugar, a Universal soube se acomodar na cultura portuguesa. Um exemplo é a reprodução da sociabilidade da "sociedade de bairro", expressão usada por Antonio Firmino da Costa. Nessa sociedade, a territorialidade é fundamental e os bairros entram em disputa entre si pelo mais "autêntico" e "genuíno", tendo sempre relações com uma sede. Não se trata, de parte da Universal, de se inserir na sociedade de bairro, mas de se apropriar desse modo de ser próprio da sociedade de bairro, onde associações locais atuam como mediadoras com o poder municipal. A Universal compôs uma rede também territorializada, formada por quase cem espaços de culto, que desde 1992 tem Lisboa como sede, mais especificamente, a Igreja do Império.

Dessa forma, a rede institucional da Universal funciona de modo semelhante ao da sociedade de bairro, onde "as igrejas também competem em uma rede nacional" (Mafra, 2001), mas, diferentemente das associações de bairro, não competem pela festa do santo mais autêntica ou majestosa

[...] e sim em termos da festa de aniversário da igreja mais luxuosa, da localidade que conseguiu trazer o homem de Deus de maior prestígio para a sua celebração local, do número de batizados do último mês, da quantidade de material arrecadado na última campanha (Mafra, 2001, p. 4).

Fica claro, porém, que diferentemente das redes voltadas para a competição, cujo ápice está na formação de uma identidade nacional, a Universal utiliza esta linguagem que não é sua, a da sociedade de bairro, como uma "linguagem de sedução", uma "[...] isca, um chamariz a partir do qual a cosmologia da IURD ganhará credibilidade" (Mafra, 2001, p. 4), constituindo-se num espaço de expressão dos insatisfeitos com aquela dinâmica de composição da identidade. Assim sendo, "a igreja Universal criou uma estratégia de entrada em Portugal que pode ser descrita como um plano de substituição da competição da festa do santo para a festa da igreja" (Mafra, 2003, p. 172).

Enfim, Mafra reconhece a importância dos pastores brasileiros da Universal para fazer a tradução, indicar os pontos de conexão entre as várias teorias implícitas no senso comum português e os preceitos normativos e doutrinários da Igreja. Em outras palavras, eles conseguem "[...] com seu discurso carregado de metáforas e palavras de múltiplos sentidos, indicar como seus seguidores poderão recriar totalizações provisórias do ponto de vista local” (Mafra, 2001, p. 10).

\section{A Igreja Universal na África do Sul}

A Universal chega à Africa do Sul em 1993, em parte através de imigrantes angolanos e moçambicanos. Mas, como refere A. Corten, desde o início ela tenta ser reconhecida não como uma igreja de imigrantes. "De dezessete templos em 1995 (principalmente na região de Johannesburgo), a IURD se estende a todas as províncias e alcança o número de 115 templos em 1998 e de 181 em 
2001 " (Corten, 2003, p. 138). Ela não tem acesso aos canais de televisão, controlados pelo Estado, mas somente às rádios e veicula seu jornal semanal Universal News com a tiragem de cem mil exemplares.

Corten recorda que a IURD chega à África do Sul no momento em que é virada a página do appartheid. Recordemos que Mandela é libertado em $1990 \mathrm{e}$ que as eleições livres ocorrem em 1994. As igrejas pentecostais cumpriram um papel ambíguo na luta contra o apartheid. A maioria delas "tinha uma tendência maior em seguir a linha da muito afrikaner NGK (Igreja holandesa reformada), que pretendeu encontrar na Bíblia um fundamento para o apartheid, em vez de adotar as posições mais progressistas das Igrejas metodista, anglicana e católica" (Corten, 2003, p. 140).

Segundo este autor, visto que as igrejas pentecostais ou do tipo pentecostal jogaram um papel ambíguo em relação ao appartheid, a IURD ocupou um lugar deixado vago. E isto se deve primeiramente ao fato de que, segundo uma leitura sul-africana da IURD, esta é uma igreja que provém do país tido como da integração racial, da mestiçagem. Em outros termos, um país da conciliação interracial, algo desejado na África do Sul após o fim legal do apartheid.

Entretanto, o fim pretendido do apartheid político não significou a solução do apartheid econômico e social. É aqui que a IURD, bem como outras igrejas que pregam a Teologia da Prosperidade, vão aproveitar de um espaço vazio. Mas, enquanto essas últimas se dirigem sobretudo às pessoas das camadas médias, a Universal se volta às camadas populares. Com efeito,

a Igreja Universal é capaz de oferecer'às populações frustradas a melhora tão esperada das condições de vida, um canal fantasmagórico de espera. O espírito de desafio e de risco, ensinado pela Universal, reforça a confiança em si mesmo $[\ldots]$. Primeiro sinal de sucesso social, encorajado nas pregações (Corten, 2003 , p. 143).

Além disso, nesse momento o poder político sul-africano se vale da ideologia do renascimento africano, concebido como um projeto de modernização visando a um novo lugar da África do Sul na economia mundial. Ora, segundo Corten,

A IURD encontra nessa ideologia do Renascimento africano e no papel que a

África do Sul se atribuiu uma concepção homóloga à sua concepção de universalidade. Esta homologia [...] se repete, na fase atual, de forma bastante simétrica, frente ao neoliberalismo. O modelo de crescimento da IURD tem a ver com uma estratégia de multinacional, implantando-se aqui e fechando em outro lugar em função de estudos de mercado" (Corten, 2003, p. 144).

Percebe-se, portanto, que o relativo sucesso da implantação da Universal na África do Sul deve-se ao fato de que esta Igreja soube se adaptar ao momento histórico do país. Segundo as palavras de Corten, a "IURD parece ter descoberto um papel específico a desempenhar no contexto pós-apartheid, oferecendo um imaginário de mobilidade social e associando-se ao papel do Renascimento africano" (Corten, 2003, p. 145). 


\section{Uma igreja que patina}

Se, por um lado, a Universal consegue se inserir em alguns países, logrando implantar, como vimos, dezenas de templos e atrair milhares de pessoas, em outros, e talvez sejam a maioria, ela encontra problemas de inserção local. Vejamos três países em que isto ocorre.

\section{A Universal no Uruguai}

Tudo indica que no mesmo período em que a Universal atingiu a Argentina, no final da década de 1980, ela também ingressou no Uruguai, instalando um templo na cidade de Rivera, na fronteira com a cidade brasileira de Livramento. Portanto, sua entrada no Uruguai se deu através da fronteira. Há controvérsias, porém, sobre o ano exato de chegada na capital do país. Seja como for, e diferentemente da Argentina, durante toda a década de 1990 ela vai erguer poucas igrejas no Uruguai, refletindo os problemas de produção de um discurso atrativo para a mentalidade uruguaia. Em 1998, estive na sede central da IURD em Montevidéu, situada então na rua Fernandez Crespo, num antigo cinema alugado, e constatei a baixa afluência de público aos cultos. Ademais, a sede estava literalmente rodeada por cinco santerias, isto é, por lojas de vendas de artigos e produtos de religiões afro-brasileiras, que ali estavam instaladas antes de a IURD se estabelecer na área. Numa tarde, o pastor brasileiro responsável pela igreja, em pé comigo diante da igreja vazia, e olhando as pessoas que circulavam nas mencionadas santerias, disse-me, com um certo ar de desânimo: "éh! aqui o demônio é muito forte" (Oro, 1999).

Alguma expansão numérica de templos no Uruguai, que retrata também a atração social exercida pela igreja, ocorre somente a partir da virada do milênio e coincide com o ingresso da IURD na mídia. Ou seja, uma das razões importantes do fracasso da década de 1990 no Uruguai radica no incipiente, para não dizer quase inexistente, uso da mídia naquele país. Mas a partir do ano 2000, quando ela contrata o seu primeiro espaço na televisão, verifica-se também uma maior procura pelos seus serviços religiosos. Por isso, em 2001 ela já contabilizava um total de catorze templos no país e hoje são dezesseis no interior do país e seis em Montevidéu, além de 28 locais de oração, chamados "anexos" (Guigou e Rovitto, 2004).

De fato, o ingresso na mídia televisiva e radiofônica foi decisivo para a IURD começar um lento processo de implantação no país. Um olhar retrospectivo mostra que tal ingresso se deu em três distintas etapas. A primeira ocorreu no ano 2000, quando a IURD contratou o espaço de meia hora diária por ocasião do encerramento da transmissão no Canal 12 Teledoce, de alcance nacional, e algumas horas de programação radiofônica que ia ao ar nas madrugadas. Tratava-se, fundamentalmente, em ambos os meios, do programa Pare de Sufrir, composto de testemunhos e imagens de orações gravados na Argentina. A segunda etapa ocorre no ano seguinte, com a ampliação para uma hora do horário televisivo, 
permitindo a introdução de novos "blocos", como a "simulação de casos reais". Nesta etapa, começa-se a falar em "encostos" e se faz referência explícita às "casas de espíritos" e "casas de encostos". A terceira etapa começa em 2003, com uma mudança no formato, no conteúdo e na extensão dos programas televisivos, que passam a difundir testemunhos e imagens locais e a reproduzir semelhante performance ritualística que ocorre nos templos do Brasil. Também houve o aumento para "dois programas diários de pelo menos uma hora e duas horas, respectivamente, nos principais canais de televisão aberta de alcance nacional (Canal 10, Saeta TV e Canal 12, Teledoce)" (Guigou e Rovitto, 2004).

Todo esse investimento midiático foi decisivo para tirar a igreja da morosidade em que se encontrava, mostrando, assim, o acerto da afirmação de Regina Novaes, para quem, bem de acordo com o "espírito da época", "as religiões não seriam as mesmas sem o uso que fazem da mídia” (Novaes, 2002, p. 89).

Outro elemento importante que contribuiu para a IURD conhecer algum "progresso" no Uruguai foi a introdução, naquele país, da mesma belicosidade contra as religiões afro-brasileiras que realiza no Brasil. Isto porque, e diferentemente da Argentina, as religiões afro-brasileiras estão há muito mais tempo implantadas no Uruguai, pelo menos desde a década de 1950, e elas recolhem neste país uma melhor legitimação social do que na Argentina (Frigerio, 1998 e Pi Hugarte, 1998). Seus freqüentadores assíduos podem chegar a $5 \%$ em Montevidéu (Da Costa e outros, 1996, p. 88).

Ora, a satanização das entidades do panteão afro-brasileiro e o discurso desqualificador dos seus seguidores, ou seja, a introdução da "guerra santa" no Uruguai (Guigou e Rovitto, 2004), provocou duas reações que, de alguma forma, beneficiaram a IURD: a) conseguiu atrair mais pessoas para os seus templos possivelmente, mas não exclusivamente, indivíduos que, tal como no Brasil, compartilham as crenças do campo afro-brasileiro e b) deu maior publicização à IURD, na medida em que ocorreram várias reações, também de caráter público, de líderes religiosos e simpatizantes do campo afro-uruguaio ${ }^{8}$.

Seja como for, as duas situações que envolvem a IURD no Uruguai, a saber: a sua atual importante presença na mídia e a introdução neste país da "guerra santa", constituem, segundo Guigou e Rovitto, "acontecimentos não freqüentes no campo político uruguaio, embora não seja ainda possível determinar se se trata de fatos unicamente pontuais ou de indícios de mudanças profundas” (Guigou e Rovitto, 2004).

\section{A Universal no México}

A presença da Universal no México data do final dos anos de 1980, mas a sua autorização oficial para funcionar foi bastante complicada e ela somente ocorreu em 2001. Neste período, mais especificamente entre 1994 e 2000, “cinqüenta pastores brasileiros da IURD teriam sido expulsos" do país (Doran, 2003, p. 95), devido justamente ao fato de que a igreja não estava registrada como asso- 
ciação religiosa. Portanto, estaria atuando ilegalmente no país. Isto porque, segundo a legislação mexicana concernente às Associações Religiosas e Culto Público, o registro só pode ser concedido a uma instituição religiosa que comprove sua presença no país há pelo menos cinco anos. A IURD tentou, sem sucesso, tal registro em 1996 e em 1999, obtendo-o finalmente em primeiro de junho de 2001.

Como veremos mais à frente, os entraves legais constituem somente um obstáculo enfrentado pela IURD no México, onde é chamada de Iglesia Universal Del Reino de Dios Oración Fuerte al Espiritu Santo. Mesmo assim, se levarmos em conta o número de templos implantados, ela conseguiu um pequeno progresso, uma vez que, de onze templos instalados em 1995, chegou a dezoito em 2001 e parece alcançar 24 na atualidade. A sede principal da igreja, chamada de Santuário de la Fé, se situa no antigo Teatro Silvia Pinal, na cidade do México, adquirido em 2001 por aproximadamente quatro milhões de dólares (Reyes, 2004). Os fiéis mexicanos da IURD "parecem pertencer às classes médias ou empobrecidas, mas em nenhum caso miseráveis” (Reyes, 2004, p. 94). Ou seja, trata-se de grupos sociais próximos ao perfil já referido na Argentina.

Os problemas enfrentados pela IURD no México são, em grande medida, os mesmos de outras igrejas evangélicas. Daí porque, segundo Freston, neste país o conjunto do protestantismo alcançava somente $5,2 \%$ da população em 2000 (Freston, 2001). A maior dificuldade da IURD, mas não só dela, é o lugar central que o Guadalupismo ocupa neste país. Ou seja, há, historicamente, um imaginário católico do milagre arraigado na cultura mexicana em torno da Virgen de Guadalupe, que permite introduzir "práticas tais como as oferendas e certas danças rituais inaceitáveis na Igreja Católica ou no pentecostalismo tradicional" (Doran, 2003, p. 97). Além disso, os fiéis mexicanos, especialmente das camadas baixas da sociedade, elaboram em torno da figura da Virgem todo um conjunto de práticas religiosas (ações mágicas, ofertas, contratos, pedidos, promessas, devocionismo pessoal), que uma igreja como a IURD geralmente explora. Ou seja, o espaço religioso que geralmente a IURD ocupa já está, em grande medida, preenchido pelo Guadalupismo.

Mas, tudo indica que no México, tal como ocorreu no Uruguai, alguma melhoria da situação da IURD em termos de arregimentação de fiéis e, conseqüentemente, de expansão do número de templos, ocorreu quando ela passou a investir fortemente na mídia, embora haja naquele país uma legislação que autoriza uma organização religiosa a ocupar a mídia somente "de maneira extraordinária".

Segundo a jornalista mexicana Laura Reyes, “a IURD investe cerca de cinco milhões de pesos mensais em matéria de publicidade nos meios eletrônicos" ". Além disso, transmite diariamente uma programação radiofônica na cadeia Radiorama assim como todos os dias o programa noturno Pare de Sufrir no canal 4 de Televisa (Reyes, 2004). Tais programas, como ocorre em outros países, sobretudo no Brasil, centralizam-se em testemunhos de milagres, entrevistas de vidas recuperadas, apelos à freqüência nos templos. Da mesma forma como já 
vimos em relação ao Uruguai, também no México são exibidas gravações realizadas pela IURD em outros países, notadamente na Argentina.

Portanto, os obstáculos enfrentados pela IURD no México são de ordem prática (a legislação do país) e de ordem simbólica (o culto à Virgem de Guadalupe). Mas ela está tentando superar tais problemas pelo investimento forte nas mídias televisiva e radiofônica, como faz no Brasil e em todos os países em que a legislação permitir.

\section{A Universal na França}

De acordo com M. Aubrée, a IURD iniciou as suas atividades na França pela região parisiense, em 1992, quando foi registrada na subprefeitura de Meaux. Logo após, instalou-se na capital, próximo à "Gare du l'Est", e três anos mais tarde ela se encontra na rua do Faubourg Saint-Martin, no térreo de um prédio novo, nos limites de três distritos parisienses $\left(10^{\circ}, 18^{\circ}, 19^{\circ}\right)$ que reúnem o maior número de migrantes de origem africana (Aubrée, 2003).

Ao que parece, em poucos países a Igreja Universal conheceu mudanças tão importantes quanto as ocorridas na França. Mudanças que tem a ver com o perfil social e étnico dos seus fiéis e com as condições políticas e jurídicas do país.

De fato, nos primeiros anos, a sua clientela era formada predominantemente por imigrantes portugueses, em porcentagens que variavam entre $90 \% \mathrm{e}$ $95 \%$, os demais sendo parisienses de certa idade. A tônica dos pronunciamentos dos pastores recaía sobre a dimensão psicológica do sofrimento, tal como verificado na Argentina, acima mencionado. Mas, a partir de 1996, verifica-se uma mudança na composição social dos freqüentadores da Universal. Há um refluxo dos portugueses e um ingresso de africanos provenientes de países lusófonos, além de cameronenses, mauricianos e marfinenses. Ainda de acordo com Aubrée, a mudança de clientela não obedece a questões'étnicas mas ao fato de que os primeiros freqüentadores da IURD eram, em sua maioria, dissidentes da Assembléia de Deus que, porém, desertaram da IURD alegando a forte pressão econômica que sofriam em relação ao dízimo e às ofertas (Aubrée, 2003, pp. 190-191).

A mudança de público implicou na mudança dos pastores, que eram brancos e agora negros, assim como mudança no discurso, onde os termos "bruxaria" e "feitiçaria" passaram a ser empregados. Neste novo contexto, a ênfase aos aspectos psicologizantes e a realização de cultos relativamente tranqüilos cederam lugar a rituais performáticos que desembocavam em violentas possessões.

A partir do ingresso "africano" na Igreja, os pastores abriram templos em Lion e Marselha, ao mesmo tempo em que, em 1999, a IURD comprou o cinema La Scala. No entanto, e de forma semelhante ao que ocorrera no Porto com o Coliseu, a reação foi grande, sobretudo de parte de artistas e cineastas. Após mobilizações, ocorreu uma reversão da aquisição daquela sala de espetáculo.

Este fato revelou que a IURD aparecia na lista dos grupos religiosos constantes na Missão Interministerial de Luta contra as Seitas. Ou seja, ela apareceu 
publicamente na condição de seita, num período - iniciado, aliás, na década de 1970 - em que o tema estava não somente na imprensa, mas em organismos de Estado e fora dele, e, até mesmo, no Congresso Nacional ${ }^{10}$.

Esta conjunção de elementos ocorridos a partir de 1999 provocou um recuo da IURD na França. A igreja de Marselha fechou, em Paris o número de seguidores diminuiu, e as condições políticas e jurídicas pouco favorecem a igreja. Por isso, no dizer de Aubrée, "podemos considerar a dinâmica atual como um declínio...” (Aubrée, 2003, p. 195).

O caso da França mostra, de um lado, como a IURD procura sempre se adaptar ao país e ao perfil social dos seus freqüentadores. Isto porque ela sabe que se não pronunciar um discurso que seja significativo aos seus seguidores, estes obviamente a abandonarão em favor de outras organizações religiosas presentes no campo religioso. Mas o caso da França mostra, também, ao menos para a Universal, que as especificidades políticas e legais de cada país são decisivas para o êxito ou fracasso de sua implantação.

\section{Conclusão}

Patricia Birman afirma, com razão, que a empreitada da Universal no exterior provoca sentimentos contraditórios para nós brasileiros. Nas suas palavras,

Hesita-se entre o orgulho patriótico e um certo mal-estar identitário quando se comenta o sucesso da Igreja do Bispo Macedo no exterior. Sua presença na Europa e na Africa, seus pastores, saídos das favelas cariocas, em Londres, Paris, Lisboa ou Buenos Aires, não deixam de causar estupefacto e relativa dificuldade para avaliar o sentido social e moral desse percurso "brasileiro" "lá fora” (Birman, 2001, p. 60).

Mas, ao mesmo tempo, há que se reconhecer que a Universal tem, em certo sentido, contribuído para invertir a tendência do fluxo religioso em relação ao Brasil, que se historicamente foi de fora para dentro, agora está sendo também de dentro para fora. Para tanto, colaborou o momento histórico em que a IURD apareceu no cenário religioso brasileiro e internacional, ou seja, em tempos de globalização. É possível que este momento favorável tenha potencializado e mesmo contribuído para a transnacionalização desta igreja. Mas, se assim for, esses "ventos favoráveis" constituíram apenas o "cenário" da transnacionalização. O êxito de instalação e desenvolvimento no exterior se deu, como mostramos neste texto, à capacidade de adaptação no exterior, constituindo cada país um caso particular, em muitos vendo-se que ela prospera e em outros que ela patina.

\section{Notas}

1 Para Freston, a primeira onda consiste na introdução do pentecostalismo no Brasil, vindo dos Estados Unidos e trazido por pastores que fundaram a Congregação Cristã (Luigi Franceson), em 1910, e a Assembléia de Deus, em 1911 (Daniel Berg e 
Gunnar Vinger). Caracteriza-se pela ênfase na glossolalia e tem como ponto doutrinal básico o batismo no Espírito Santo.

A segunda onda inicia com a fragmentação do campo pentecostal onde desponta a Igreja do Evangelho Quadrangular, fundada em 1951, e as igrejas Brasil para Cristo (fundada em São Paulo, em 1955, por Manuel de Mello) e Deus é Amor (fundada em São Paulo, em 1962, por David Martins Miranda). Caracteriza-se, sobretudo, pela ênfase nos rituais de cura e na organização institucional empreendimentistaempresarial (inicia o ingresso na mídia, na política, renovação dos rituais numa relação de aproximação e de combate com a religiosidade popular presente no catolicismo e nas religiões mediœnicas).

A terceira onda começa no final dos anos de 1970 e ganha força nos anos de 1980 com o surgimento das igrejas Sara Nossa Terra (fundada em 1980 por Robson Rodovalho), Universal do Reino de Deus (fundada no Rio de Janeiro em 1977 por Edir Macedo), Renascer em Cristo (fundada em 1986 pelo casal Estevam e Sonia Hernandes), Internacional da Graça de Deus (fundada no Rio de Janeiro em 1980 por Romildo R. Soares), entre outras. Caracterizam-se pelo exclusivismo frente ao resto das expressões pentecostais e evangélicas, ênfase nas teologias da prosperidade e da guerra espiritual, investimento forte na mídia (impressa, radiofônica, televisiva e informatizada) e na política, e expansão de sua presença para alem das fronteiras nacionais. Tudo isto, acompanhado de um nível pouco intenso de exigências, permitindo uma diversificação e ampliação de suas bases sociais de recrutamento.

Evidentemente que não há fronteiras claras entre as três ondas. Elas também não se superpõem e o pentecostalismo brasileiro se caracteriza justamente pela interação dos estilos provenientes das três ondas referidas (Freston, 2000).

Para uma visão histórica e uma análise atual do pentecostalismo brasileiro, bem como sua inserção na cultura brasileira, ver Mariano, 1999; Pierucci e Prandi, 1996; Sanchis, 1977.

2 Segundo dados constantes no próprio site da Igreja, hoje ela "está com 8.146 igrejas, espalhadas pelo Brasil e mais em 136 países de todo o mundo". Ainda segundo o site, vê-se que ela está presente em todos os continentes. Mas, tal como ocorre com a IURD, parece que na maioria dos países a sua presença no exterior é quantitativamente modesta.

3 De acordo com o site oficial dessa Igreja, ela dispõe atualmente de 992 igrejas/ templos no Brasil, e no exterior possui cinco templos em Portugal, dois nos Estados Unidos, um na Inglaterra, um no Japão, um no Uruguai, um na Holanda, e anuncia para breve a instalação de uma igreja na França.

4 Para uma análise das controvérsias destes termos na Antropologia francesa ver Capone, 2002.

5 Acreditamos que se poderia acrescentar ainda um terceiro modelo de transnacionalização religiosa. Seria aquele onde são as idéias que circulariam, especialmente via mídia (imprensa, rádio, televisão, internet), não sendo acompanhadas por migrações populacionais ou por indivíduos que as difundiriam. Seria o caso da receptividade ocidental de algumas expressões e formas religiosas orientais.

6 Efetuei uma primeira versão desta parte do texto em Oro, 2004. 
7 Segundo Freston, a IURD dá grande ênfase ao seu trabalho social: distribuição de comida e roupa, trabalho com drogados, pessoas idosas e órfãs. Desta forma, ela procura a legitimidade negada por importantes setores sociais portugueses (Freston, 2001, pp. 203-204).

8 Sobretudo os dirigentes do jornal Atabaque, Pai Julio (Kronberg) de Omolu e mãe Suzana (Andrade) da Oxum, enviaram cartas às autoridades dos poderes executivo, legislativo e judiciário, compareceram na mídia, abriram processo judicial contra a IURD, sempre evocando a condição de cidadãos uruguaios que dispõem dos direitos constitucionais de exercer a sua religião, que repousa na tradição nacional de respeito às minorias e acusando os pastores da IURD de serem "estrangeiros intolerantes" que violam as leis e as tradições locais e respeito aos outros cidadãos (Frigerio e Oro, 2004).

9 Esse valor corresponde a aproximadamente $\mathrm{R} \$ 57.000,00$.

10 De fato, segundo Giumbelli, “desde a década de 1970, o tema (das "seitas") tornouse sinônimo de inquietação nas matérias veiculadas pelos jornais e TVs e justificou a criação de associações especificamente dedicadas à denœncia e ao combate das "seitas" e à defesa de suas "vítimas". Em seguida, as "seitas" converteram-se em uma preocupação governamental, gerando estudos, debates jurídicos e aparatos específicos. O tema continua mobilizando as atenções de jornalistas e também de representantes das igrejas cristãs tradicionais e cientistas sociais" (Giumbelli, 2002, p. 18).

Bibliografia

AUBREE, Marion. "La diffusion du pentecôtisme brésilien en France et en Europe: le cas de l'I.U.R.D». Em LERAT, Christian e RIGAL-CELLARD, B. (orgs.). Les mutations transatlantiques des religions. Bordeaux, PUB, 2000, pp. 149-157.

AUBREE, Marion. "A Igreja Universal na França”. Em ORO, Ari Pedro; CORTEN, André e DOZON, Jean-Pierre (orgs.). Igreja Universal do Reino de Deus: os novos conquistadores da Fé. São Paulo, Paulinas, 2003, pp. 189-198.

BADIE, Bertrand e SMOUTS, M. C. Le retournement du monde: sociologie de la scène internationale. Paris, Presse de la Fondation Nationale des Sciences Politiques \& Dalloz, 1992.

BIRMAN, Patrícia. "Conexões políticas e bricolagens religiosas: questões sobre o pentecostalismo a partir de alguns contrapontos”. Em SANCHIS, Pierre. Fiéis ê Cidadãos. Rio de Janeiro, Ed. UERJ, 2001, pp. 59-86.

CAPONE, Stefania. "Du pareil au même": olhares criticos da antropologia francesa sobre as noções de globalização, transnacionalização e postmodernismo. Paper apresentado na 23ํ Reunião Brasileira de Antropologia, Gramado, Brasil, 16-19 jun. 2002.

CORTEN, Andre. "A Igreja Universal na África do Sul”. Em ORO, Ari Pedro; CORTEN, André e DOZON, Jean-Pierre (orgs.). Igreja Universal do Reino de Deus: os novos conquistadores da Fé. São Paulo, Paulinas, 2003, pp. 137-146.

CORTEN, André. "A Igreja Universal: uma máquina multinacional que responde às novas necessidades religiosas". Revista de Cultura, Petrópolis, Vozes, 2002, pp. 3847 . 
DA COSTA, Nestor e outros. 'Creencias y religiones: la religiosidad de los montevideanos al fin del milênio. Montevideo, Trilce, 1996.

DORAN, Marie-Christine. "A Igreja Universal no México”. Em ORO, Ari Pedro; CORTEN, André e DOZON, Jean-Pierre (orgs.). Igreja Universal do Reino de Deus: os novos conquistadores da Fé. São Paulo, Paulinas, 2003, pp. 93-100.

FRESTON, Paul. “The Political Evolution of Brazilian Pentecostalism: 1986-2000”. Em CORTEN, Andre e MARY, Andre (orgs). Imaginaires Politiques et Pentecôtisme: Afrique et Amérique. Paris, Karthala, 2000, pp. 287-306.

. "The transnationalisation of Brazilian Pentecostalism. The Universal Church of the Kingdom of God". Em CORTEN, Andre e MARSHALL-FRATANI, Ruth (orgs.). Betweeen Babel and Pentecostalism. Transnational Pentecostalism in Africa and Latin America. London, Hurst \& Company, 2001, pp. 196-215.

FRIGERIO, Alejandro. La expansión de religiones afro-brasileñas en el Cono-Sur: representaciones conflictivas de cultura, raza y nación en un contexto de integración regional. Paper apresentado no seminário "Dimensions of Integration: NAFTA and MERCOSUR", Universidade de Nuevo México, Albuquerque, 20-21 nov. 1998.

FRIGERIO, Alejandro e ORO, Ari Pedro. "Guerre sainte dans le Cône Sud latinoaméricain: Les religions afro-brésiliennes et leurs réponses aux attaques de l'Eglise Universelle du Royaume de Dieu». 2004, a sair na revista L'Homme, Paris.

GIUMBELLI, Emerson. O fim da religião. São Paulo, Attar Editorial, 2003.

GUIGOU, Nicolas e ROVITTO, Yamila. "Más allá del bien y del mal: la Iglesia Universal del Reino de Dios en el Uruguay". Texto inédito.

MAFRA, Clara. "A Igreja Universal em Portugal”. Em ORO, Ari Pedro; CORTEN, André e DOZON, Jean-Pierre (orgs.). Igreja Universal do Reino de Deus: os novos conquistadores da Fé. São Paulo, Paulinas, 2003, pp. 165-176.

Na posse da palavra. Religião, conversão e liberdade pessoal em dois contextos nacionais. Lisboa, Instituto de Ciências Sociais da Universidade de Lisboa, 2002.

Sobre a qualidade da mediação institucional da Igreja Universal do Reino de Deus (IURD) com foco no caso de Portugal. Paper apresentado na Conferência da SISR em Ixtapan de la Sal (México), 20-24 ago. 2001.

MARIANO, Ricardo. Neopentecostais: sociologia do novo pentecostalismo no Brasil. São Paulo, Loyola, 1999.

NOVAES, Regina. "Crenças religiosas e convicções políticas: fronteiras e passagens". Em FRIDMAN, Luis Carlos (org.). Política e Cultura. Século XXI. Rio de Janeiro, Alerj/ Relume Dumará, 2002, pp. 63-98.

ORO, Ari Pedro e SEMAN, Pablo. "Brazilian Pentecostalism Crosses National Borders". Em CORTEN, Andre e MARSHALL-FRATANI, Ruth (orgs.). Betweeen Babel and Pentecostalism. Transnational Pentecostalism in Africa and Latin America. London, Hurst \& Company, 2001, pp. 181-195.

ORO, Ari Pedro. Axé MERCOSUR. As religiões afro-brasileiras nos países do Prata. Petrópolis, Vozes, 1999. 
. "La transnationalisation du pentecôtisme brésilien. Le cas de l'Eglise Universelle du Royaume de Dieu”. Civilisations. vol. LI, n. 1-2, Bruxelles, 2004, pp. 155-170.

PI HUGARTE, Renzo. Los cultos de posesión en Uruguay. Montevideo, Ed. De la Banda Oriental, 1998.

PIERUCCI, Antonio Flavio e PRANDI, Reginaldo. A realidade social das religiões no Brasil. São Paulo, Hucitec, 1996.

REYES, Laura Islas. "En el reino de Dios. Y con las promesas en la televisión”. Informe Etcétera, jul. 2004.

SANCHIS, Pierre. "Pentecostalismo e cultura brasileira". Religião e Sociedade. vol. 18, n. 2, 1997, pp. 123-126.

SEGATO, Rita. "Formações de diversidade: nação e opções religiosas no contexto da globalização". Em ORO, Ari Pedro e STEIL, Carlos Alberto (orgs.). Globalização e Religião. Petrópolis, Vozes, 1997, pp. 219-248.

SEMAN, Pablo e MOREIRA, Patrícia. "La Iglesia Universal Del Reino de Dios en Buenos Aires y la recreación del diablo a través del realineamiento de marcos interpretativos". Em Sociedad y Religión. Buenos Aires, n. 16/17, 1998, pp. 95-110.

SEMAN, Pablo. "A Igreja Universal na Argentina". Em ORO, Ari Pedro; CORTEN, André e DOZON, Jean-Pierre (orgs.). Igreja Universal do Reino de Deus: os novos conquistadores da Fé. São Paulo, Paulinas, 2003, pp. 69-78.

RESUMO - ESTE TEXTO analisa a dimensão transnacional de uma igreja neopentecostal "brasileira", a Igreja Universal do Reino de Deus, presente na atualidade em oitenta países. Serão privilegiados três países em que ela obteve sucesso (Argentina, Portugal e çfrica do Sul) e três outros em que ela encontra problemas para deslanchar (Uruguai, México e França). Nos três primeiros será visto como essa igreja consegue neles se enraizar e se adaptar às culturas locais, garantindo-lhe, assim, algum triunfo, contrariamente aos três outros onde ela enfrenta obstáculos locais que lhe fazem patinar.

RÉsumé - CE TEXTE analyse la dimension transnationale d'une église neopentecôtiste "brésilienne", à savoir l'Église Universelle du Royaume de Dieu, présente de nos jours dans quatre-vingt pays. On va privilégier trois pays dans lesquels elle a du succès (l'Argentine, le Portugal et l'Afrique du Sud), et trois autres où elle a des problèmes pour démarrer (l'Uruguay, le Mexique et la France). Concernant les trois premiers pays on verra comment cette église a réussi à s'enraciner localement et à s'adapter aux cultures locales, tout en obtenant de la sorte quelque trionphe, contrairement aux trois derniers pays où elle a dû faire face à des obstacles locaux et par conséquent elle a du mal à démarrer.

Ari Pedro Oro é professor do Departamento de Antropologia da Universidade Federal do Rio Grande do Sul (UFRGS).

Texto recebido e aceito para publicação em 20 de setembro de 2004. 